\title{
遠隔転移を有さない腎細胞癌に対する術後補助療法の検討
}

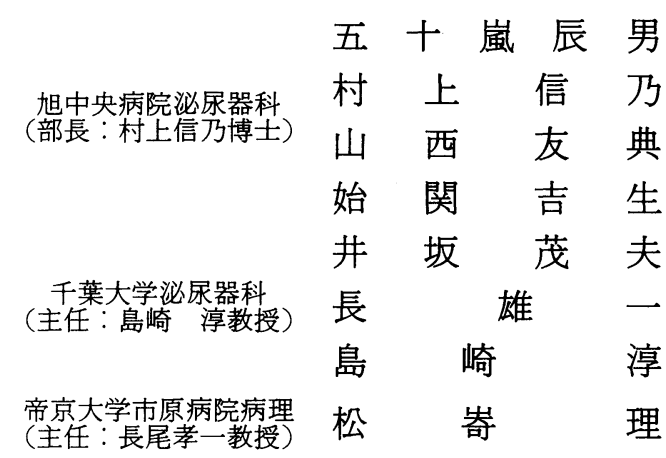

\section{EFFECTS OF POSTOPERATIVE ADJUVANT THERAPIES FOR RENAL CELL CARCINOMA}

\author{
Tatsuo Igarashi, Shino Murakami, Tomonori Yamanishi and Yoshio Shiseki \\ Department of Urology, Asahi General Hospital \\ Shigeo Isaka, Yuichi Osa and Jun Shimazaki \\ Department of Urology, Chiba University, School of Medicine \\ Osamu Matsuzaki \\ Department of Pathology, Ichihara Hospital, Teikyo University, School of Medicine
}

One hundred and eleven patients of renal cell carcinoma without distant metastasis were treated by radical nephrectomy during the last 25 years. In 92 of these patients, several forms of postoperative adjuvant therapies were performed. These include irradiation to the tumor bed, various forms of anticancer chemotherapy and progestin therapy. The remainder of these patients received no adjuvant therapies, and are regarded as the control group.

To evaluate the effects of adjuvant therapies, survival rates of each of the two groups were compared. And these patients were classified by pT category and pathological grade. Patients with pT1 or pT2a tumor had good prognosis regardless of the form of adjuvant therapy. The survival rate of patients with grade 1 tumor was improved by any of the aforementioned adjuvant therapies. Moreover, chemotherapy significantly improved the survivfal rate of patients with pT2b tumor. But these adjuvant therapies showed no benefit for the patients with pT3, grade 2 or 3 tumor. For such patients, another method should be investigated.

\footnotetext{
要旨：千葉大学泌尿器科および旭中央病院泌尿器科で過去 25 年間に腎摘術を施行した193例のうち, 手術 時遠隔転移を有さず経過観察が十分であり, 術後 1 力月以上生存した111例を対象とし, 術後補助療法の 効果を生存率の比較により検討した。補助療法は放射線療法, 化学療法, プロゲスチン療法に分け, そ れぞれ grade 別, pT 別に検討した. その結果 grade 別では grade 1の症例ですべての補助療法が有効で あったが, grade 2 3の症例ではすべてが無効であった. pT 別では pT2b の症例で化学療法が有効で あったにとどまり, 他は有意差が認められなかった. grade 2〜3, pT3の症例に対しては新しい補助療法 の開発が必要であると思われた.
}

\section{緒 言}

遠隔転移を有さない腎細胞癌術後の補助療法とし
てここれまでにさまざまな治療法が試みられてきたが， 未だに一定の見解が得られていない. 
今回われわれは, 術後に実施された補助療法の効果 につき，生存率を比較することにより，検討を加えた ので報告する。

\section{対象, 方法}

1960年 1 月より，1985年10月までに千葉大学泌尿器 科および旭中央病院泌尿器科で腎摘除術を施行し, 病 理組織学的に腎細胞癌と確認された患者は193例であ るが,このらち手術時遠隔転移を有さないものは156例 である。このうち術後の補助療法施行の有無が明確な 117 例中, 術後 1 力月以内死亡である手術死 6 例を除外 した111例を対象とした。腎摘除術は大部分が経腹的に おこなった。

pT, grade は腎癌取り扱い規約 ${ }^{1)}$ 従った。複数の成 分が存在する場合には, 悪性度の高いところで決定し た. 生存率の算出は Kaplan-Meier 法") により，2 群間 の生存率の検定は Mantel一Haenszel test ${ }^{3)}$ 用いて, 5 年の期間で評価した。

補助療法は, a. 放射線療法, b. 化学療法, c. プロゲ スチン療法の 3 種類に分類した。このらち, 治療法が 2 つ以上重複するものは, それぞれの項目にいれて 扱った。

それぞれの治療法の内訳は以下に示すとうりであ る.放射線療法は術後腎茎部または腫瘍床にテレコバ ルトまたはリニアックを4,000 rad 以上照射した。経静 脈的化学療法は単剤では mitomycin (MMC) を40mg 以上，または toyomycin を $10 \mathrm{mg}$ 以上，もしくは $5 \mathrm{FU}$ を7,500mg 投与した。多剤併用療法は MMC，5FU， cytosine arabinoside の併用 (MFC), cis-diami-nedichloroplatinum (CDDP), adriamycin (ADM), cycrophosphamide の併用 (CAP), CDDP, ADM, 5FU の併用（CAF）のいずれかがおこなわれた，経口的に は5FU, UFT, フトラフールのいずれかが, 維持療法と して投与された。プロゲスチン療法は 1 日量として酢 酸クロルマジノン $100 \mathrm{mg}$ ，または酢酸メドロキシプロ ゲステロン $90 \mathrm{mg}$ がそれぞれ原則として 1 年以上経口 投与された。

\section{結 果}

1. 治療法の種類, 重複拉よび pT, grade 分布

表 1 は選択された治療法の種類, 組み合わせ怙よび それぞれの pT, grade 分布である。術後補助療法を まったくおこなわなかった症例は19例であり，これを コントロール群とした。 3 種類の治療法のうちいずれ かを単独でおこなったものは61例であり，a. 放射線療 法31例, b. 化学療法25例, c. プロゲスチン療法 5 例で
表 1 補助療法の種類と pT, grade分布

\begin{tabular}{l|c|c|c|r|r|r|r|r}
\hline & \multicolumn{4}{|c|}{$\mathrm{pT}$} & \multicolumn{3}{c|}{ grade } & \multirow{2}{*}{ 計 } \\
\cline { 2 - 7 } & 1 & $2 \mathrm{a}$ & $2 \mathrm{~b}$ & 3 & 1 & 2 & 3 & \\
\hline なし (コントロール) & 1 & 0 & 9 & 9 & 8 & 9 & 2 & 19 \\
a. 放射線 & 0 & 2 & 9 & 20 & 9 & 16 & 6 & 31 \\
$\mathrm{~b}$. 化学療法 & 1 & 2 & 7 & 15 & 10 & 11 & 4 & 25 \\
$\mathrm{c}$. プロゲスチン & 0 & 1 & 2 & 2 & 2 & 3 & 0 & 5 \\
$\mathrm{a}+\mathrm{b}$ & 0 & 1 & 4 & 5 & 4 & 4 & 2 & 10 \\
$\mathrm{a}+\mathrm{c}$ & 0 & 1 & 2 & 1 & 2 & 2 & 0 & 4 \\
$\mathrm{c}+\mathrm{a}$ & 0 & 0 & 1 & 10 & 5 & 4 & 2 & 11 \\
$\mathrm{a}+\mathrm{b}+\mathrm{c}$ & 0 & 1 & 3 & 2 & 4 & 1 & 1 & 6 \\
\hline
\end{tabular}

あった. 2 者併用は 3 通り 25 例, 3 者併用は 6 例であっ た.

2. $\mathrm{pT} 1 \sim 2 \mathrm{a}$ 症例の予後

$\mathrm{pT} 1 \sim 2 \mathrm{a}$ は全体で10例であり，そのらちコントロー ル群は 1 例のみであった。また 1 例が 9 年 3 カ月で他 の疾患で死亡した。 その他は最長 19 年 4 カ月, 最短 5 カ月で経過観察中であるが, 全例癌再発を認めていず, これらの症例の予後は, 補助療法の有無に関係なく良 好であった。

3. コントロール群の生存率

$\mathrm{pT} 1 \sim 2 \mathrm{a}$ 以外の 5 年生存率は $\mathrm{pT} 2 \mathrm{~b}, 51.9 \pm 29.7 \%$, pT3, 66.7 $20.2 \%$ であり, grade 別では $1 ， 2 ， 3$ そ

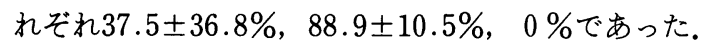
10 年生存率は $\mathrm{pT} 2 \mathrm{~b}, 51.9 \pm 29.7 \%, \mathrm{pT} 3,66.7 \pm$ $20.2 \%$ であり, grade 1,2 では 5 年から 10 年の間に死亡 例はなかった。

4. 放射線療法に関する生存率

図 1 に放射線療法施行の有無による生存率を示す。 5 年生存率を比べると $\mathrm{pT} 2 \mathrm{~b}$ で, 本療法施行群 $86.9 \pm$ $9.3 \%$, 本療法以外の他療法施行群 (以下他療法群) $100 \%, \mathrm{pT} 3$ で本療法施行群, $43.6 \pm 19.2 \%$, 他療法群 $37.5 \pm 30.0 \%$, grade 1では本療法施行群 $88.5 \pm 8.1 \%$, 他療法群 $91.7 \pm 8.0 \%$, grade 2 では本療法施行群 $60.6 \pm 15.8 \%$, 他療法群 $60.8 \pm 22.0 \%$ であった. grade 3 では 2 年生存率で本療法施行群 $36.4 \pm 31.9 \%$, 他療法 群 $0 \%$ だあった。

以上より grade 1においてのみ, 本療法施行群の生 存率はコントロール群に比べ有意に良好であったが $(\mathrm{p}<0.05), \mathrm{pT} 2 \mathrm{~b} \sim 3$, grade 2 3では有意差を認めな かった.

5. 化学療法に関する生存率

図 2 に化学療法施行の有無による生存率を示す。 5 年生存率を比べると pT2b で本療法施行群 $100 \%$, 他療 
図 1 放射線療法と他療法との生存率の比較

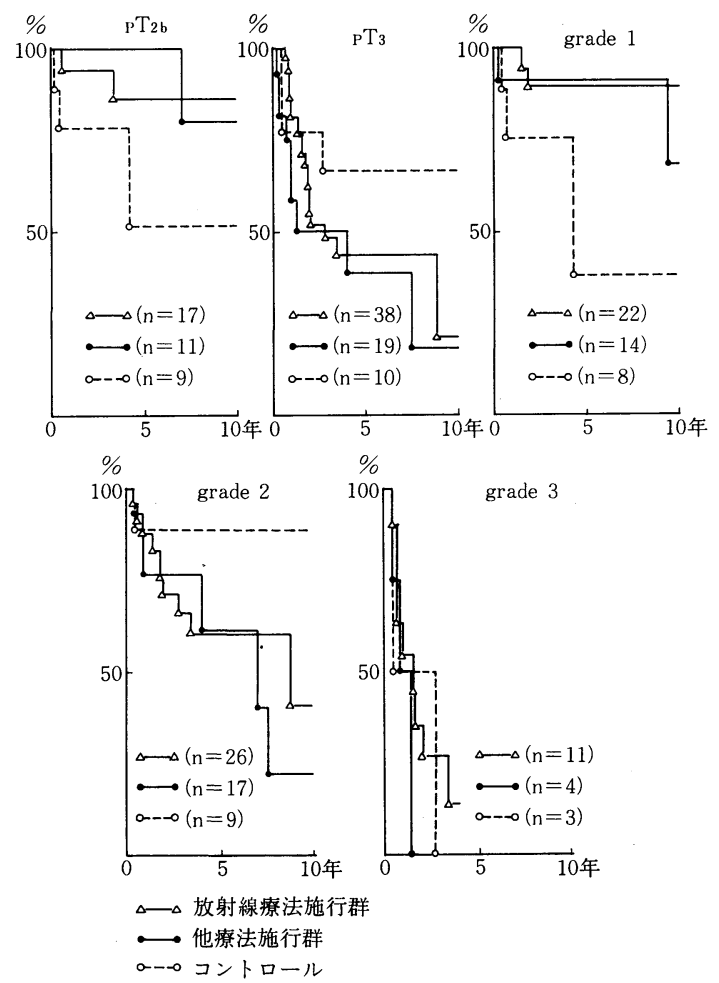

図2 化学療法と他療法との生存率の比較

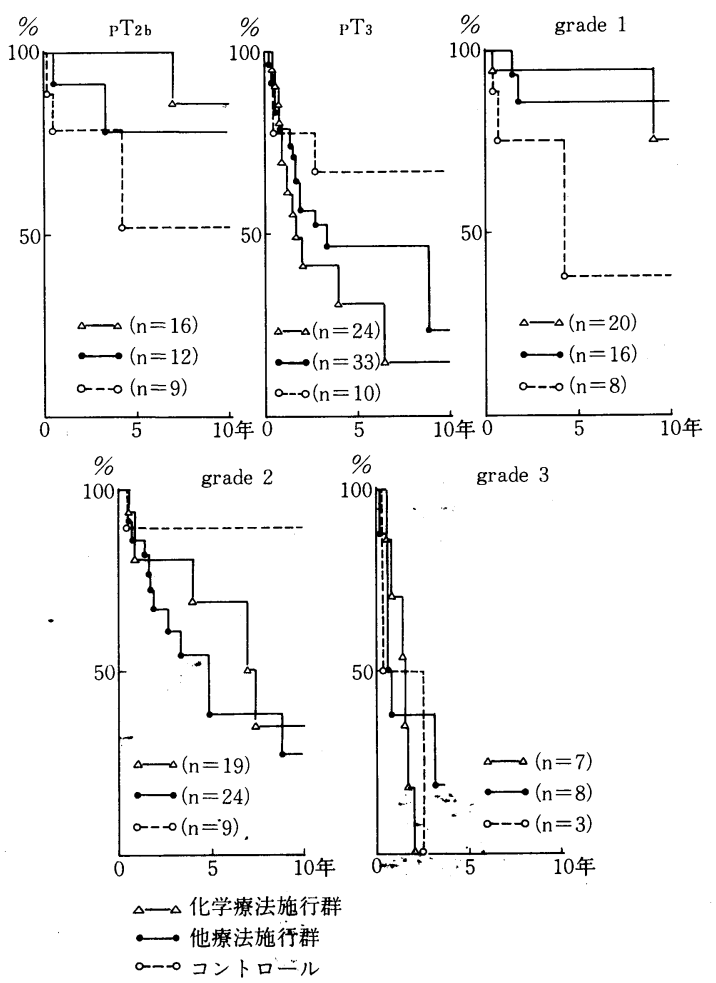

図 3 プロゲスチン療法と他療法との生存率の比較

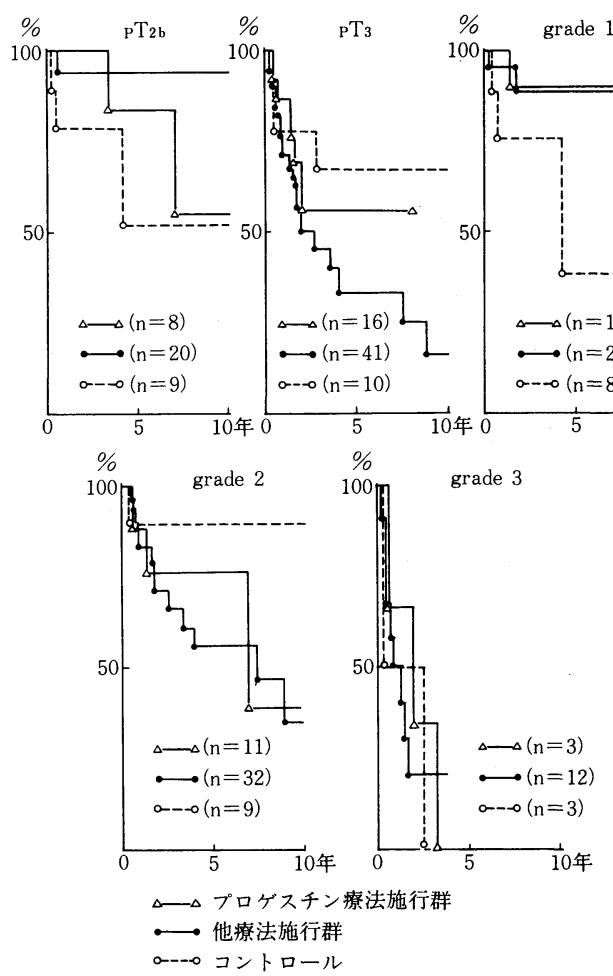

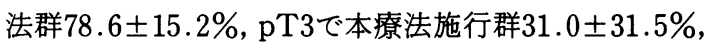
他療法群 $46.8 \pm 19.0 \%$, grade 1では本療法施行群 $94.4 \pm 5.4 \%$, 他療法群 $85.6 \pm 10.2 \%$, grade 2 では本 療法施行群 $68.9 \pm 17.1 \%$, 他療法群 $54.3 \pm 19.1 \%$ で

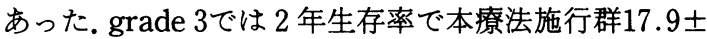
44.9\%, 他療法群37.5士34.2\%であった。

以上より $\mathrm{pT} 2 \mathrm{~b}$, grade 1で本療法施行群の生存率は コントロール群と比べ，有意に良好であった（ $\mathrm{p}<$ 0.01)。 また他療法群と比べると, pT2b, grade 2で有 意に良好であった（ $\mathrm{p}<0.05 ）$.

pT3, grade 3ではコントロール群, 他療法群との間 に有意差をみとめなかった。

6. プロゲスチン療法に関する生存率

図 3 にプロゲスチン療法施行の有無による生存率を 示す． 5 年生存率を比べると pT2b で本療法施行群 $83.3 \pm 15.2 \%$, 他療法群 $94.4 \pm 5.4 \%$, pT3で本療法施 行群 $56.7 \pm 22.3 \%$, 他療法群 $33.5 \pm 24.4 \%$, grade $1 て ゙$ は本療法施行群 $90.0 \pm 9.5 \%$, 他療法群 $89.4 \pm 7.5 \%$, grade 2では本療法施行群 $76.2 \pm 16.6 \%$, 他療法群 $55.2 \pm 17.4 \%$ であった. grade 3 の 3 年生存率は本療法 施行群 $33.3 \pm 40.8 \%$, 他療法群 $20.0 \pm 41.3 \%$ であった。 
以上より本療法施行群の生存率は grade 1に扔いて のみコントロール群より有意に良好であった（ $\mathrm{p}<$ 0.05).しかし, pT2b〜3, grade 2 3では差はなく, 他療法群と比較しても良好ではなかった。

1. 効果判定の方浩について

転移巣を有さない腎癌の術後補助療法に関し, これ までにさまざまな努力が払われて来たが，現段階では それぞれについて評価するのが方法論的に極めて困難 と思われる。

たとえば, stage IVのように評価可能病変を有する ものについては, 腫瘍の大ささの経時的変化に対し, 抗腫瘍効果を論ずることができるが，評価可能病変を 有さない場合効果判定の基準を何に求めるかにより結 果が左右されると考学れれるからである.

この点に関し近年腫瘍再発確認までの tumor free 期間で評価を試みる報告4)55があり, 術後補助療法の目 的が腫瘍再発予防にあるとするならば，正しい方法と 言党よう。しかし，いつ再発したかという時間的な特 定については最近では大西ら ${ }^{6)} 1$ 年単位で評価し, 里見ら 7 む同様に 5 年以降 1 年単位で述べている。 た, 臨床的に発見される転移藏器と剖検によるそれと の間の差異については岡ら8)の指摘するところであ り, すなわち再発臓器の確認抢よびその時期の特定は 困難である症例が少なくないと思われる，われわれの 全193例の集計では癌死例78例のうち, 腫瘍再発時期が 特定できたものは 20 例（26.0\%）であり, 非再発率を 評価するのは事実上不可能であった。したがって今回 は生存率をもって補助療法の効果判定の一助とした が, 他の論文の多くが同様の方法で論じているのを考 慮しても現時点ではこれがもっとも説得力のある方法 と考えられる。

\section{2. 放射線療法について}

放射線療法の意義については局所再発予防を第一義 とするのが諸家の一致する点である(4) ${ }^{414)}$.

これには本腫瘍が局所再発に次いで全身転移を来た すといら見地 ${ }^{11)} り$ その防止の重要性が説かれてお ク，Riches ${ }^{12)}$ を始めとして，この予防に有効であった といら意見があり, これを裏付けている。一方, 腎腫 揚の局所再発の頻度について, 近年 Parienty ${ }^{15)}$ は CT スキャンによる検索をもとに 75 例中 8 例 $(10.7 \%)$ と 報告し, さらに再発例は stage III IV や, 腎部分切除 術を施行した手術的に根治性が低い症例に多いと述べ ている。また, Feher ら ${ }^{14)} は$ 逆の視点より経腹式, 経胸
腹式に Gerota を含めて腫瘍を摘除した場合，腎窩部 に関する限り十分に摘除できる症例が殆どであるとし ている。この点を近年 Brady $^{13}$ ) は総括して, 本療法は, 1. 腎窩部，2．腎静脈内，3，局所リンパ節などに腫瘍 細胞が残存すると考えられる場合や，4．手術時に腫瘍 細胞が播種された可能性がある場合に適応であろうと している.

更に放射線療法の生存率に拈よぼす効果については 議論が多く, 興味深いところであるが, Peeling ${ }^{10)}$, Flock ら ${ }^{91} に$ 代表されるように，これを改善し得たと

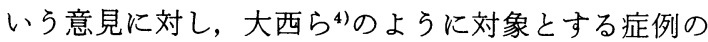
stage, grade 等の背景因子が不明確であるといら批判 がある。近年でも本療法に対する術後補助療法として の評価は一定でないが，予後改善にはあまり有効でな

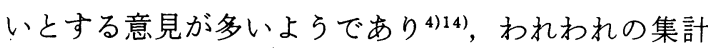
でも同様に生存率の改善に寄与する例は少ないと思わ れた。

副作用については最近 Feher ら ${ }^{14)} は ，$ 術後放射線照 射を施行した 29 例中 4 例（13.8\%）がその障害により 死亡したと報告しているょうに，決して軽いものでな く前述した理由も含めて, 本療法の適応には慎重さが 必要とされると思われる。

3. 化学療法について

現在のところ腎細胞癌に対する化学療法の効果はき

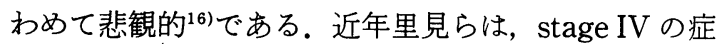
例に対し $\mathrm{MFC}^{17)}, \mathrm{CCNU}^{18)}$, FT-207, vinblastine ${ }^{19}$ に よる治療を試み, FT-207に $8 \%$ の有効率を認めたのみ で他は有効例はなかったと述べているが，これは諸家 の報告と一致している。

経口的投与では5FU 201,21$)$ 打よび masked compound ${ }^{22), 23)}$ が使用され，これらは時間依存性作用 群に含まれるので合理的と言えよう. $5 \mathrm{FU}$ の抗腫瘍効 果については増田ら ${ }^{20}$ は, 術後肺転移例 3 例中 2 例に 完全寛解を認めたと報告している反面, 岡田ら ${ }^{211}$ は 6 例全例無効としている。またUFTについては最近志 田ら ${ }^{22}$ は 10 例中 3 例 (30\%) に有効で，そのらち 2 例に 完全寛解を認めたと報告し, 小関ら ${ }^{23)}$ はインターフェ ロンとの併用で 8 例中 3 例 (37.5\%) に有効であった と述べている，いずれも奏効率 $30 \%$ という良好な成績 であるのは注目すべきであろう。

一方近年ではインターフェロン療法による成績が報 告されている24)がまだ評価しうる段階でないようであ る.

腫瘍の再発予防効果について実証した報告はない201 
が, 生存率の改善に関するものでは, 阿曾ら ${ }^{11}$ は血沈え 進例に対する化学療法の有用性を, 増田ら ${ }^{25}$ は COMA 療法の有用性を述べている。われわれの集計は多種の 薬剂を包括的に扱っているので個々の薬剤については 言及できないが，本療法は少なくとも p T 2b，grade 1 において有効であり，また grade 2においては他療法 より有効であったので，今後さらに薬剤の選択，投与 法の工夫などにより成績の向上が期待できると思われ た。

一方，本療法の副作用で留意すべきなのは骨髄抑制 であるが，経口的投与では一般に軽度 ${ }^{20123)}$ とされ，諸 家の報告を見ても少ないようである。しかし，静脈内 投与では問題となることが多く, 白血球減少や血小板 減少のおこる頻度は里見らによると MFCで $30 \%{ }^{17)}$, CCNU で57\% ${ }^{18)}$, vinblastine で36\% ${ }^{19)}$ と報告し，これ による死亡例も散見される。したがって，本療法に踏 み切る際には副作用に十分留意すべきであろう。

4. プロゲスチン療法について

プロゲスチン療法の有用性については議論の多いと ころである。担癌症例に対するものでは, Alberto ら ${ }^{26)}$ のように有効例なしとするまったく否定的な意見もあ るが，一方本療法を OK432 27), vinblastine ${ }^{28)}$ と併用し 完全寛解を得たとする報告も散見される．Bojar ${ }^{29}$ は 有効率に関し，内分泌療法全体を総括して，完全宽解 $1.6 \%$, 部分寛解 $7 \%$ 以下と述べているが，近年小林

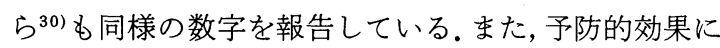
ついては里見ら 5)は本療法が良好な傾向を示したと述 べ, Bracci $5^{31}$ \& pT2 3, N0 1, M0の症例で生存率

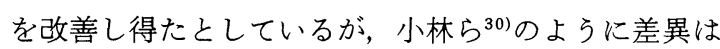
なかったとする報告もある。われわれの集計では本療 法施行群の予後はgrade 1で良好であったのみで, 全 体としては有意差はなく, 他の補助療法と比較しても 優れているとは思えなかった。

\section{まとめ}

腎細胞癌の術後補助療法について検討したが，わず かに low stage, low grade 症例の一部で予後が良好で あったとするにとど亲た。. 全体としては依然として 現在のところ有効なものはないと思われる。

したがって新たな治療法の開発の必要性が痛感され るが，このらち化学療法はもっとも有効な治療法と考 えられ, 研究の余地のある分野であると思われる。薬 剂の選択，投与経路，投与する時期などについても今 後更に検討されるべきであろう。

\section{結語}

1. 千葉大学泌尿器科, 旭中央病院泌尿器科におい て，1960年 1 月より，1985年10月をでに腎摘除術を施 行した腎細胞癌193例のらち, 手術時遠隔転移を有さ ず, 術後補助療法施行の有無が明確で, 術後 1 力月以 上生存した111例を対象として, 術後補助療法の延命効 果を生存率比較により検討した。

2. $\mathrm{pT} 1 \sim 2 \mathrm{a}$ は症例数が少なく，かつ補助療法と関 係なく長期の生存を見た。

3. pT2bの症例は化学療法により, 生存率が有意に 改善された。

4. grade 1の症例では放射線療法, 化学療法, プロ ゲスチン療法のいずれかにより生存率が改善された。

5. pT3または grade 2〜3の症例では補助療法の有 無が生存率に影響せず，これらに対しては新しい補助 療法の開発が必要と思われた。

尚, 本論文の要旨は第23回日本癌治療学会において報告 した。

\section{文献}

1) 日本泌尿器科学会, 他編: 腎癌取扱い規䄪. 72-73, 金原出版, 東京, 1983.

2) Kaplan, E.L. and Meier, P.: Nonparmetric estimation for incomplete observations. J. Am. Stat. Assoc., 53, 457-481, 1958.

3) Mantel, N.: Chi-squre tests with onedegree of freedom: Extensions of the Mantel-Haenszel procedure. J. Stat. Assoc., 58, 690-700, 1963.

4) 大西哲郎, 増田富士男, 仲田浄次郎, 鈴木正泰, 飯 塚典男, 町田豊平: 腎細胞癌の放射線治療効果. 日 泌尿会誌, 76, 1154-1160, 1985.

5) Satomi, Y., Takai, S., Kondo, I., Fukushima, S. and Furuhata, A.: Postoperative prophylactic use of progesterone in renal cell carcinoma. J. Urol., 128, 919-922, 1982.

6）大西哲郎，町田豊平，増田富士男，荒井由和，仲田 浄治郎, 鈴木正泰：腎細胞癌の術後転移に関する 臨床および病理組織学的検討. 日泌尿会誌, 75, 681 -687, 1984.

7）里見佳昭, 仙賀 裕, 福田百邦, 中橋 満, 西村隆 一, 大島博幸, 近藤猪一郎, 吉邑貞夫, 福島修司, 古畑哲彦, 石塚栄一, 福岡 洋: 腎癌患者の10年生 存率及び10年以上生存例の検討. 日泌尿会誌, 75, $118-125,1984$.

8）岡直友, 長谷川辰寿：転移からみた腎癌の臨床 成績について。 日泌尿会誌，59，311－322，1968。

9) Flocks, R.H. and Kadesky, M.C. : Malignant neoplasms of the kidney: An analysis of 353 patients followed 5 years or more. J. Urol., 79, 
196-201, 1958.

10) Peeling, W.B.: Postoperative irradiation in the treatment of renal cell carcinoma. $\mathrm{Br}$. J. Urol., 41, 23-31, 1969.

11）阿曾佳郎，小磯謙吉，岡田清己，星野嘉伸，村橋 勲：予後からみた腎癌手術と化学療法および放射 線療法併用の評価。日泌尿会誌，65，209-217， 1974.

12) Riches, E. : The place of radiotherapy in the management of parenchymal carcinoma of the kidney. Trans. Am. Assoc. Genitourin. Surg., 57, 120-124, 1965.

13) Brady, L.W. Jr.: Carcinoma of the kidneyThe role for radiation therapy. Seminars in Oncology, 10, 417-421, 1983.

14) Feher, M., Pinter, J. and Szokoly, V.: Problems of the indications of radiotherapy in renal tumours after radical nephrectomy. Int. Urol. and Nephrol., 16, 29-32, 1984.

15) Parienty, R.A., Richard, F., Pradel, J. and Vallancien, G.: Local recurrence after nephrectomy for primary renal cancer : Computerized tomography recognition. J. Urol., 132, 246-249, 1984.

16）真田寿彦：腎細胞癌の予後. 日泌尿会誌，72, 10-25, 1981.

17）里見佳昭, 高井修道, 中橋 満, 古畑哲彦：腎細胞 癌の化学療法一第 1 報 MFC 療法. 日泌尿会誌, 73, 1422-1430, 1982 .

18）里見佳昭, 高井修道, 中橋 満 : 腎細胞癌の化学療 法一第 2 報 CCNU 単独療法. 日泌尿会誌, 73, 1431 $-1435,1982$.

19）里見佳昭, 仙賀 裕, 福田百邦, 中橋 満, 大島博 幸, 古畑哲彦: 腎細胞癌の化学療法一第 3 報 Ft207, vinblastine 単独療法. 日泌尿会誌, 75, 903 $-908,1984$.

20）増田富士男, 木戸 晃, 荒井由和, 町田豊平 : 腎細 胞癌の肺転移に対する5-FU dry syrup 投与の臨 床経験. 癌と化学療法, 6, 1139-1145, 1979.

21）岡田謙一郎, 池田達夫, 小松洋輔, 吉田 修: NI(2'-Tetrahydrofuryl)-5-fluorouracil (Futraful) に よる泌尿器科領域覀性腫瘍の治療について. 癌と
化学療法, 5, 605-613, 1978.

22）志田圭三, 山中英寿, 伊藤善一, 島崎 淳, 井坂茂 夫, 横川正之, 福井 㦑, 川井 博, 秋元成太, 吉 田和弘, 町田豊平, 増田富士男 : 泌尿器悪性腫瘍に 対する UFT の Phase II Study. 癌と化学療法, 11, 1307-1314, 1984.

23）小関清夫, 赤座英之, 岸 洋一, 梅田 隆, 岩動孝 一郎, 新島端夫：進行腎癌に対する UFT の臨床 成績. 癌と化学療法, 12, 2061－2064， 1985.

24）井坂茂夫, 岡野達弥, 秋元 晋, 島崎 淳, 村上信 乃, 五十嵐辰男, 北村 温, 山口邦雄, 片海七郎, 大塚 薫, 松村 勉: 進行腎癌に対する組換え型 ヒトインターフェロン $\alpha$ の使用経験. 泌尿紀要, 31, 2209-2214, 1985.

25）増田富士男, 佐々木忠正, 荒井由和, 小路 良, 仲 田浄治郎, 大西哲郎, 鈴木正泰, 町田豊平: 腎細胞 癌に対する手術・合併療法の効果と問題点. 泌尿紀 要, 28, 843-851, 1982.

26) Alberto, P. and Senn, H.J.: Hormonal therapy of renal carcinoma alone and in association with cytostatic drugs. Cancer, 33, 1226-1229, 1974.

27）長倉和彦, 高尾雅也, 松崎章二, 家田和夫：プロゲ ステロンおよび溶連菌製剤により肺転移巣の完全 退縮をみた進行腎細胞癌の 1 例. 日泌尿会誌, 76, 1909-1913, 1985.

28) Rahima, M.M. and Barzilay, J.: Regression of pulmonary metastases with long term remmission in patient with renal carcinoma. Thorax, 40, 201-202, 1985.

29) Bojar, H.: Hormone responsiveness of renal cancer. World J. Urol., 2, 92-98, 1984.

30）小林幹男, 今井強一, 中井克幸, 鈴木孝憲, 永田雅 弥, 伊藤善一, 山中英寿 : 腎細胞癌の治療. 第一報 ホルモン療法。泌尿紀要, 31, 1531-1537, 1985.

31) Bracci, U., DiSilverio, F. and Concolino, G. : Hormonal therapy of renal cell carcinoma (RCC). Renal tumors : Proceedings of the First International Symposium on Kidney Tumors, 623-640, Alan R. Liss, Inc., New York, 1982.

(1986年 6 月 2 日受付) 